\title{
Pre-treatment serum vascular endothelial growth factor is associated with clinical response and overall survival in advanced melanoma patients treated with ipilimumab
}

Jianda Yuan ${ }^{1 \dagger}$, Jun Zhou ${ }^{5+}$, Zhiwan Dong ${ }^{1}$, Sapna Tandon', Deborah Kuk ${ }^{3}$, Katherine S Panageas ${ }^{3}$, Philip Wong ${ }^{1}$, Jedd D Wolchok ${ }^{1,2,4}$, F Stephen Hodi ${ }^{*}$

From Society for Immunotherapy of Cancer 28th Annual Meeting

National Harbor, MD, USA. 8-10 November 2013

Ipilimumab, an antibody that blocks cytotoxic $\mathrm{T}$ lymphocyte antigen 4 (CTLA-4), had shown improved overall survival (OS) for patients with metastatic melanoma. However predictive biomarkers for clinical benefit have not been well defined. We aimed to evaluate serum vascular endothelial growth factor (VEGF) and its association with clinical benefit and OS for ipilimumab treated advanced melanoma patients. Sera were collected from 176 patients treated with ipilimumab at $3(\mathrm{n}=98)$ or $10 \mathrm{mg} / \mathrm{kg}(\mathrm{n}=68)$ from 2005 to 2013. We analyzed serum VEGF at baseline and at the end of induction (week 12) by Meso Scale Discovery kit. The association VEGF with clinical benefit and OS was analyzed using Fisher's exact test and KaplanMeier log-rank test. Pre-treatment VEGF value correlated with clinical benefit for 157 melanoma patients with the availability of clinical response at wk24 $(\mathrm{p}=0.0111)$ using

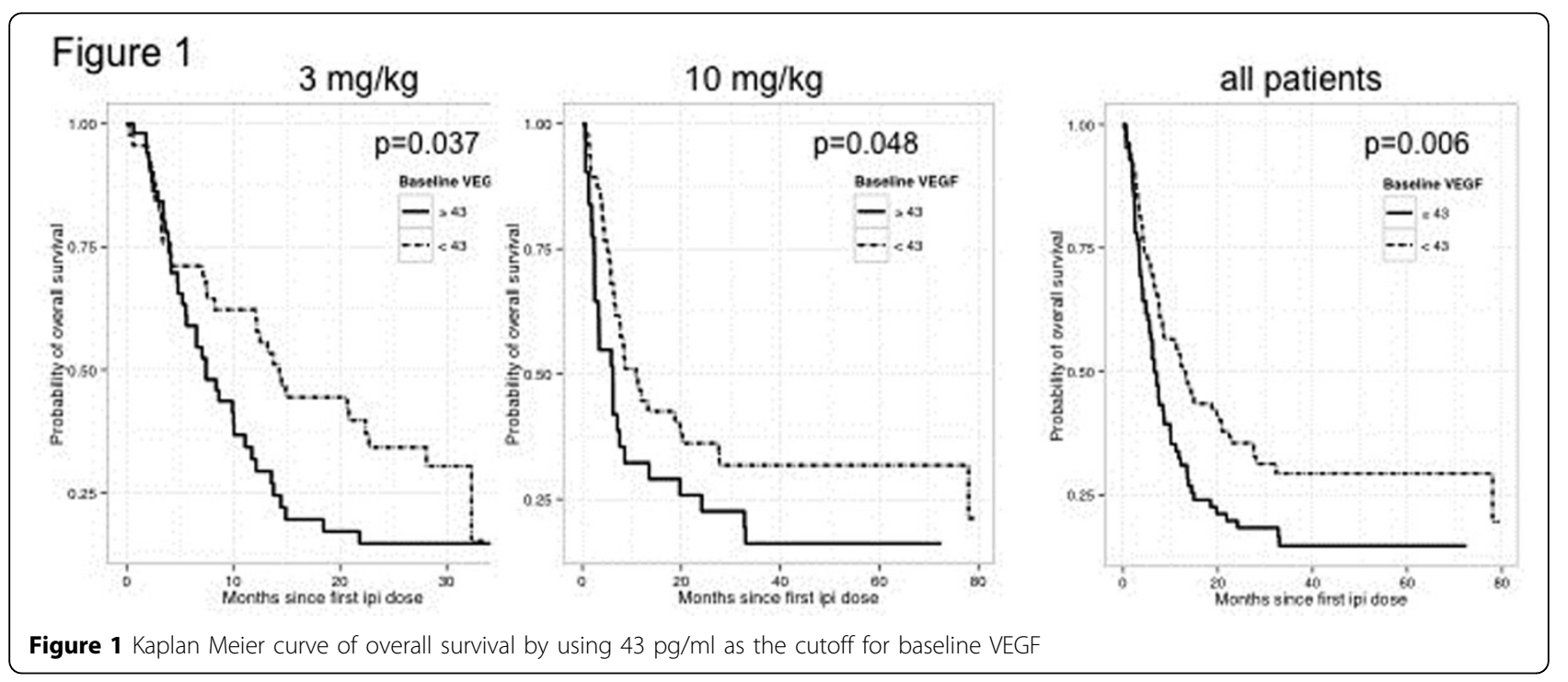

† Contributed equally

${ }^{5}$ Department of Medical Oncology, Center for Immuno-oncology, Dana-

Farber Cancer Institute and Harvard Medical School, Boston, MA, USA

Full list of author information is available at the end of the article

(C) 2013 Yuan et al; licensee BioMed Central Ltd. This is an Open Access article distributed under the terms of the Creative Commons 
$43 \mathrm{pg} / \mathrm{ml}$ as the cutoff of baseline VEGF value defined by maximally selected log-rank statistics. High level of soluble pre-therapy VEGF ( $\geq 43 \mathrm{pg} / \mathrm{ml}$ ) in blood was associated with decreased OS, as compared to low level baseline VEGF ( $<43 \mathrm{pg} / \mathrm{ml}$ ) (Median OS 6.6 vs 12.9 months, $\mathrm{p}=0.006$ for all 176 patients; median OS 7.4 vs 14.3 months, $\mathrm{p}=0.037$ for $3 \mathrm{mg} / \mathrm{kg}$ group; median OS $6.2 \mathrm{vs}$ 10.9 months, $\mathrm{p}=0.048$ for $10 \mathrm{mg} / \mathrm{kg}$ group, respectively). High level of soluble VEGF at wk12 was correlated with OS in all patients as well $(\mathrm{p}=0.023)$. There was no correlation between the change of VEGF and clinical outcome. Serum VEGF may be a predictive biomarker to ipilimumab treatment, and prospective investigation warranted.

\section{Authors' details}

${ }^{1}$ Ludwig Center for Cancer Immunotherapy, Memorial Sloan-Kettering Cancer Center, New York, NY, USA. ²Department of Medicine, Memorial Sloan-Kettering Cancer Center, New York, NY, USA. ${ }^{3}$ Department of Epidemiology and Biostatistic, Memorial Sloan-Kettering Cancer Center, New York, NY, USA. "Weill Cornell Medical College of Cornell University, New York, NY, USA. ${ }^{5}$ Department of Medical Oncology, Center for Immuno-oncology, Dana-Farber Cancer Institute and Harvard Medical School, Boston, MA, USA

Published: 7 November 2013

doi:10.1186/2051-1426-1-S1-P247

Cite this article as: Yuan et al:: Pre-treatment serum vascular endothelial growth factor is associated with clinical response and overall survival in advanced melanoma patients treated with ipilimumab. Journal for ImmunoTherapy of Cancer 2013 1(Suppl 1):P247.

\section{Submit your next manuscript to BioMed Central} and take full advantage of:

- Convenient online submission

- Thorough peer review

- No space constraints or color figure charges

- Immediate publication on acceptance

- Inclusion in PubMed, CAS, Scopus and Google Scholar

- Research which is freely available for redistribution

Submit your manuscript at www.biomedcentral.com/submit 